\section{Trakya Eğitim Dergisi}

Cilt 10, Sayı 2

May1s 2020, 488-504

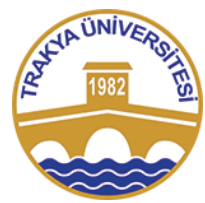

ISSN : 2630-6301

Doi: $10.24315 /$ tred.583046
Trakya Journal of Education

Volume 10, Issue 2

May 2020, 488-504

Gelis Tarihi: 27.06.2019.

Araştırma Makalesi

Yayına Kabul Tarihi:03.04.2020.

Research Article

\title{
Temel Edebi Unsurlarla Resimli Hikâye Kitabı: İngiliz Dili Öğretmen Adaylarının Kitaplarını Öz-Değerlendirmeleri
}

\section{Picture Storybooks With Basic Literary Elements: Elt Prospective Teachers' Self-Assessments of Their Books}

\section{Şule ÇELİK KORKMAZ ${ }^{1}$,}

ÖZ: $\mathrm{Bu}$ çalışma, 101 3.sınıf İngiliz Dili Eğitimi öğretmen adayının yabancı dil olarak İngilizce öğrenen çocuklar için hazırladıkları resimli hikâye kitaplarının öz değerlendirmelerini araştırmıştır. Öğretmen adaylarına kitaplarının öz değerlendirmelerini yapmaları için 23 maddelik beșli likert ölçeğinde bir anket uygulanmıştır. Anketin maddeleri temel edebi öğeleri ve çocuklara yabancı dil öğretim kriterlerini içeren iki kategoriyi işaret etmektedir. Ek olarak, öğretmen adaylarının öz değerlendirmelerinin sonuçları uzmanların değerlendirmelerinin sonuçlarıyla karşılaştırılmış ve sonuçlar yazarlarla yapılan yarı yapılandırılmış mülakat sonuçlarıyla detaylandırılmıştır. Genel sonuçlar, yazarların kitaplarını özellikle metinler ve görüntüler arasında etkili iletişimlere, eğitici temalara, iyi tasarlanmış kapak sayfalarına, kapsamlı başlıklara, tanıdık karakterlere ve müfredata uygun senaryolara sahip olmaları açısından başarılı bulduklarını ortaya çıkarmıştır. Yazarların değerlendirmeleriyle karșılaştırıldı ğında, bazı maddelerin uzmanlar tarafından daha fazla ya da daha az değer biçilerek değerlendirildiği görülmüştür.

Anahtar sözcükler: Resimli hikâye kitabı, temel edebi unsurlar, çocuklara İngilizce öğretimi, İngiliz Dili Ĕ̆itimi öğretmen adaylarl, öz değerlendirme

Bu makaleye atıf verin /

\begin{abstract}
The study investigated the quality of 101 3rd year ELT prospective teachers' picture story books (totally 20) for EFL children via their self-assessments. The prospective teachers were given a 23-item five-point likert questionnaire to do their selfassessments for the books. The items of the questionnaire refer to two categories involving basic literary elements and the particular criteria for teaching young learners. In addition, the results of the authors' assessments were compared to the experts' assessments and elaborated through the results of the authors' semi-structured interviews. The overall results revealed that they believed their books were successful particularly in terms of having effective icono-texts, deductive themes, well-design cover pages, comprehensible titles, familiar characters, and the scripts compatible with the curriculum. When compared to the authors' assessments, it was seen that some items were overrated or underrated by the experts.
\end{abstract}

Keywords: Picture story book, basic literary elements, teaching English to young learners, ELT prospective teachers, selfassessment

Çelik-Korkmaz, Ş. (2020). Picture storybooks with basic literary elements: ELT prospective teachers' self-assessments of their books. Trakya Ë̆itim Dergisi, 10(2), 488-504.

Cite this article as:

Çelik-Korkmaz, Ş. (2020). Picture storybooks with basic literary elements: elt prospective teachers' self-assessments of their books. Trakya Journal of Education, 10(2), 488-504.

\section{Giriş}

\section{UZUN ÖZET}

Bland (2013b) çocuk okuyucu olabilmenin yolunun çocuk edebiyatından, özellikle de görsel okuryazarlık kazanmak için çok önemli olan resimli kitaplardan geçtiğini vurgularken birçok ilkokul İngilizce öğretmeni tarafından resimli kitapların faydalarının bilinmemesinin çocuk edebiyatının dil öğretiminde kullanılması konusunda direnç oluşturduğunu belirtmiştir. Aynı şekilde, Konomi (2014) tarafindan Korça Arnavutluk'ta, ilkokul seviyesinde yabancı dil olarak İngilizce öğretiminde öğretmenlerin ne boyutta görsel materyal kullandığıyla ilgili olarak yapılan çalışma, resimler, posterler

\footnotetext{
1 This paper was presented as an oral presentation at International Necatibey Educational and Social Science Research Congress (INESCO 2018). held at Balıkesir University on October 26-28, 2018.

${ }^{2}$ Instructor Dr., Uludağ Üniversitesi, e-posta: scelik@uludag.edu.tr
} 
ve kartpostallarla karşılaştırıldığında resimli kitapların ilkokul İngilizee öğretmenleri tarafından en az kullanılan çok algılı materyaller olduğunu ortaya çıkarmıştır

Çer (2016) ve Çer \& Şahin (2016) çocuklar için uygun olan kitapların sadece edebi kriterleri değil aynı zamanda çocukların karakteristik özelliklerinin, ihtiyaçlarının ve ilgilerinin karşılanması, onları pozitif yönde etkileyecek karakterlerin kullanılması, çocukların duygularını iletebileceği ve anlama şekillerine uygun konu ve mesajlar içermesi gibi kriterleri de karşılaması gerektiğini ifade etmișlerdir. Literatürde ticari resimli kitaplar edebiyat ve sanatı dikkate alarak farklı açılardan incelenmiştir (Catalano, 2005; Çer \& Şahin, 2016; Gönen, Uygun, Erdoğan \& Katranc1, 2012; Maria, 2016; Wagner, 2013; Wu, 2014). Fakat çocukların yabancı dil gelişimine katkı sağlamayı amaçlayan konuya özel resimli hikâye kitabı oluşturma ve inceleme açısından literatürde bir boşluk vardır. Kennedy (1987) iyi bir hikâye yazmak için sanat anlayışı geliştirmenin en iyi yolunun bir hikâye yazmak olduğunu belirtmiştir. Bu amaçla, bu çalışma İngiliz Dili Eğitimi öğretmen adaylarının kendi yazdıkları resimli hikâye kitaplarını temel bazı edebi unsurlar ve çocukların özelliklerine ve ihtiyaçlarına uygunlukları açısından nasıl değerlendirdiklerini araştırarak literatüre katkı sağlamayı amaçlamıştır. Öğretmen adaylarının öz değerlendirmeleri uzman değerlendirmeleri ile karşılaştırılarak çalışma zenginleştirilmişsir.

\section{Yöntem}

$\mathrm{Bu}$ çalışmada araştırmacı tarafından geliştirilen öz-değerlendirme anketi kullanılarak nicel, yarı yapılandırılmış mülakat uygulanarak ta nitel veri kullanılmış ve ortaya sonuçları karşılaştırma firsatı sunan karma bir araştırma deseni çıkmıştır. Bu çalışma, 2 saat teorik 2 saat de pratik toplam 4 saat olan "Çocuklara Yabanci Dil Öğretimi II" dersini alan 4 sınıftaki 75 kız 26 erkek toplam 101 Uludağ Üniversitesi İngiliz Dili Eğitimi 3. sınıf öğrencisiyle yapılmıştır. Bu ders kapsamında katılımcılardan çocuk edebiyatı hakkında bilgilenip, önceki yıllarda yapılan resimli kitapları inceleyip ve bu kitapların kalitesini tartıştıktan sonra, uygulama dersinde sunulmak üzere, çocuğa uygun müfredatla uyumlu ilkokul İngilizce öğretmenleri tarafından yüksek sesle okunmak üzere resimli hikâye kitapları oluşturmaları istendi. Kitaplar hazırlanıp uygulama dersinde kullanıldıktan bir hafta sonra öğretmen adaylarına kitaplarını değerlendirmeleri için uzman görüşü alınarak hazırlanmış öz değerlendirme anketi verildi.

5'li Likert olarak hazırlanan anket, temel edebi unsurlarla ilgili 11, çocuklara yabancı dil öğretim kriterleriyle ilgili 12 soru olmak üzere toplam 23 sorudan oluşmaktadır. Anketin güvenilirliği Cronbach alfa değeri ile $(\alpha=.93)$, geçerliliği de uzman görüşleri alınıp yeniden yapılandırılarak sağlanmıştır. Anketin uygulandığı ve devam eden üç haftalık süreçlerde katılımcıların ve araştırmacının programına göre yarı yapılandırılmış mülakatlar yapılmıştır. Öğretmen adaylarının öz değerlendirmelerinin geçerliliğini arttırmak amaciyla, 2017-18 eğitim öğretim yılı bittikten sonra 3 hafta içinde oluşturulan toplam 20 adet resimli hikâye kitabı, biri çocuklara yabancı dil konusunda uzman olan araştırmacı, diğer ikisi İngiliz Dili Eğitimi Anabilim Dalında edebiyat alanında çalışan 2 uzman tarafından değerlendirilmiştir. Değer biçiciler arası güvenilirlik katsayısı. 704 olarak bulunmuştur.

Nicel veriler SPSS programı kullanılarak yüzde, ortalama, standart sapma gibi betimleyici istatistik açısından nitel veriler ise içerik analizi kullanılarak değerlendirilmiştir.

\section{Bulgular ve Tartışma}

Katılımcılar tarafindan temel edebi unsurlar açısından öz değerlendirmesi yapılan resimli hikâye kitapları genel sonuçları katılımcıların kitaplarını en çok resim metin ilişkisi, arkadaşlık, insanlara ve hayvanlara yardım etme ve çevreye duyarlı olma gibi konularla eğitici olması, iyi tasarlanmış ön sayfa ve kapsamlı bir başlık açısından başarılı bulduklarını ortaya çıkarmıştır. Gönen ve arkadaşlarının (2012) bulgusuna paralel olarak resim metin ilişkisi konusunda bu çalışmada ortaya çıkan kitapların başarılı olması, teorik derste hedef kitlenin somut işlem döneminde olduğu ve dilin görsellerle somut hale getirilmesinin bu kitle için ne kadar önemli olduğunun vurgusunun çokça yapılmasıyla açıklanabilir. Görsel kullanımının öneminin vurgulanması, öğretmen adaylarının bu konuda daha çok emek harcamalarına sebep olmuş olabilir. Eğer çocuklar hikâye karakterlerini tanımazlarsa hikâyede anlatılmak istenen mesajı anlayıp hayatlarına uyarlayamazlar diyerek verilen eğitici mesajdaki karakter etkisini vurgulayan Strouse, Nyhout \& Ganea (2018) gibi, katılımcılar da, vermek istedikleri mesajın 
etkisini vurgulamak için hikâye kahramanlarını ilginç ve çocuğun tanıdığı karakterlerden seçmişlerdir. Karakter ve seçilen eğitici konulardaki başarı sayesinde ruhsal açıdan çocuğa uygun bir kurgu elde edilmiştir. Öz değerlendirme sonuçlarına göre en başarısız buldukları unsurlar ise iyi planlanmış bir tema, hikâyenin geçtiği zaman ve mekândır. Hikâyeler uzmanlar tarafından incelendiğinde de birçok hikâye de zaman belirteci olarak "bir gün" ifadesi kullanıldığı görülmüştür. Bu da katılımcıların zaman olarak pek detay vermediklerini göstermektedir.

Çocuklara yabancı dil öğretimi açısından da incelenen kitaplar, hikâye karakterlerinin çocuklar için tanıdık olması, dil açısından müfredatta hedeflenen yapılara ve kelimelere uygun olması, cümlelerin kolay okunabilir ve öğrenci seviyesine uygun olması ve hikâyelerin eğlenceli olmaları açısından başarılı bulunmuştur. Smallwood (2002) tarafından da açıklandığg gibi, katılımcılar da dil öğretiminde kullanılacak çocuk edebiyatı metinlerinin dil olarak çocukların seviyesinin anlaşılabilecek seviyeye kadar üstü olması, tekrarlanan ve tahmin edilebilen dil yapılarından oluşması gerektiğine inanmış ve kendilerine verilen sınıf seviyesine uygun olarak kitaplarında hedef dili başarılı bir şekilde kullanmışlardır.

Diğer taraftan, yarıya yakın katılımcı kitaplarını hikâye metinlerinin çocukların hayal gücünü harekete geçirme ve hikâye temasının çocuğu eğlendirmesi açısından başarılı bulmamışlardır. Ayrıca, yine yarıya yakın katılımcı hikâyeleri, öğrencilerin kişisel deneyimleriyle hikâyeyi bütünleştirme, öğrencileri fiziksel olarak etkin kılma, hikâye sonrası aktivitesi olarak drama kullanımına uygunluk açısından başarılı bulmamışlardır. Kendilerini en başarısız buldukları alan ise yaratıcılık olmuştur. Hikâyelerini yeterince yaratıcı bulmayan öğretmen adaylarının 21. yüzyıl becerileri arasında olan yaratıcılık konusunda güçlenmeleri öğretmen eğitimi programının içerinde önemli bir yer bulmalıdır. Öğretmen yetiştiriciler uygun olan her firsatta öğretmen adaylarını bu konuda bilgilendirmeli ve yaratıcılıklarını ortaya çıkarabilecekleri aktivitelerle derslerini zenginleştirmelidirler.

Uzman değerlendirmesi ve öğretmen adayı öz değerlendirmesi ortalama olarak karşılaştırıldığında, iki grupta oluşturulan hikâyelerde metin ve resimler konusunda uyum olduğunda, müfredatta belirtilen yapıların hikâyede kullanıldığında ve hikâye kahramanlarının çocuklar için tanıdık karakterlerden oluştuğu konusunda hikâyeleri güçlü bulmuştur. Yine aynı şekilde, öğrencilerin hayal gücünü etkinleştirmek, eğlenceli temalar oluşturmak ve öğrencilerin kişisel tecrübeleriyle hikâyeleri bütünleştirmek konusunda iki tarafta hikâyelerin yeterince güçlü olmadığını belirtmişlerdir. İki grup arasında değerlendirmede uyum olması öğretmen adaylarının sadece dil öğretiminde kullanılmak üzere resimli hikâye kitabı oluşturma açısından başarılı olduklarını değil aynı zamanda yansıtıcı düşünme becerilerini de geliştirdiklerini göstermektedir.

Öğretmen adayları giriş sayfası, kapsamlı bir başlık ekleme ve öğretici bir hikâye oluşturma açısından kendilerini başarılı bulsalar da uzmanlar adaylar kadar başarılı bulmamışlardır. $\mathrm{Bu}$ uyumsuzluk öğretmen adaylarının teorik bilgilerinin eksik olduğu ya da bu bilgileri pratiğe dökme konusunda eksiklerinin olduğunu göstermektedir. Yarı yapılandırılmış görüşmeler sonucunda da belirtildiği üzere, kapak sayfası hazırlarken öğretmen adaylarının daha çok estetik açıdan düşündükleri, çocuğu çekebilecek tasarımlar için emek verdikleri sonucuna varmak mümkündür. Diğer taraftan teorik olarak daha donanımlı olan uzmanların ise, kapak sayfasını ve başlığı, yukarıdan aşağıya işlemleme ve ön dinleme ve okuma aktivitelerine uygunluk açısından değerlendirmiş olma olasıllğı yüksektir. Bu sonuçta, öğretmen eğitiminde sadece teorik bilgilerin uygulamalarla pekiştirilmesi gerekliliğini desteklemektedir.

\section{Sonuç}

$\mathrm{Bu}$ çalışma dil öğretimi alanında kullanılmak üzere İngiliz dili eğitimi öğretmen adayları tarafından oluşturulan resimli hikâye kitaplarının yazarları tarafından öz değerlendirmelerini hedeflenmiştir. Bu konuda uzmanların da değerlendirmelerine başvurarak, bazı temel edebi eserler ve çocuklara İngilizce öğretimine uygunluk açısından oluşturulan kitapların genel olarak başarılı bulundukları sonucuna varılabilir. Öğretmenler ve öğretmen adayları ne kadar fazla materyal hazırlama konusunda sürece dâhil olurlarsa o kadar fazla hazırlanan materyalleri sınıfta kullanmaya eğilimli olurlar. Bu yüzden, sadece müfredatla uyumlu ve çocuklara uygun resimli hikâye oluşturup değerlendirmeyi kapsayan bu çalışmaya ek olarak bu kitapların kullanımının çocukların dil öğrenimindeki farklı bileşenlere etkilerini ölçecek ileri çalışmalar da yapılmalıdır. 


\section{INTRODUCTION}

Childhood was not considered as an important phenomenon until the second half of the $20^{\text {th }}$ century. Thereafter, various reforms in legislation and jurisdiction were made to protect children from exploitation, from strenuous labour, from getting married including the universal schooling which was considered essential in childhood and was made available to the public (Feldman, 2004; Lowe, 2009; Rathus, 2014). As a result of those changes, the questions related to the way children think and learn, the way they should be taught, the most possible appropriate conditions for learning in schools and the improvement of the existing circumstances have become very crucial issues in children education. As stressed by Bland (2013a), the fact that there appear many children who could not access to suitable books until school age due to a lack of books in the home environment makes the choice of texts in the formal school environment eminently important for children.

Besides inequality of opportunity for some children to reach supplementary story books to promote their language development, there appear some difficulties for language teachers to integrate additional books into their mainstream education. As reported by Kierepka (2006), teachers tend to utilize predictable activities rather than risk-taking activities such as using picture books in their classes not only due to lack of enough time in their English lessons so as to supplement their textbooks with them but also due to high language level of picture story books or too childish books which are likely to be rejected by the learners. It is more likely for Turkish EFL primary school teachers to experience similar difficulties to supplement their EFL coursebook with curriculum-oriented picture story books as the Turkish primary level state coursebooks do not comprise story books despite the suggestions of MoNE (2018) for teachers to integrate story-telling techniques in almost every unit of the primary-level curriculum. Therefore, it is probable that Turkish EFL teachers who desire to use story-telling technique into their classes might be in need of either choosing the most appropriate commercial picture story books or creating their own ones to integrate into their teaching. In accordance with this purpose, the present study aimed to assess the quality of variety of picture story books created by ELT prospective teachers (PTs) who were trained to teach English to young learners and to integrate literature into language teaching.

\subsection{Literature: Some Basic Literary Elements}

With regard to analysing a piece of literary work, there appear many terms in literature; however, focusing on some basic literary elements could be better when the case is related to children with different characteristics than adults. Some basic literary elements which refer to the tools an author needs to use when crafting a brief story can be identified as a plot, setting, character, style, and theme (Martinez, Yokota, \& Temple, 2017). Plot refers to events including ordering of the events in a story (ibid). A well-constructed plot includes internal or external conflicts to involve struggle, details and pattern of events arranged in a cause-effect relationship, climax to invite the reader to experience the greatest emotional response to a character's problem, and conclusion to resolve the conflict (Millett \& Rodrigues, 1991). Parayno (1997) stated that to love and to be loved, family affections, warm friendships were included in stories as some prominent needs of children to give them sense of security and foster positive attitudes towards their lives. Thus, children can be guided to cope with some possible fundamental problems in life through a well-written story indicating both the happiness and complications of romance. In this sense, stories about healthy family relationships, animals' defending, and protecting their young appeal children.

Character is defined as an imaginary person either as a major or minor one, a static or a dynamic one in a literary work. When choosing or creating a character, the main character is called protagonist whereas a character or force who opposes protagonist is called antagonist (DiYanni, 2000). There are four methods of characterization: "(1) describing the character's appearance; (2) reporting the character's speech and behaviour; (3) describing the reactions of other characters to the individual; and (4) revealing the character's thoughts and feelings" (Millett \& Rodrigues, 1991, p. 659).

In addition, to create and transmit a desired mood, elements such as setting, objects, specific details, and images should be carefully selected by an author (Millett \& Rodrigues, 1991). For instance, 
setting which refers to the time and place in which the events of a narrative take place contributes to the narrative including the plot, character and a certain atmosphere (ibid). The theme of the story was defined as the issue or message that readers deduced from a story (Martinez et al., 2017). They stated that a theme cannot be stated explicitly or represented via an image; thus, it is likely that different readers might deduce different meanings from the same story. The style is described as a way of using a language by an author including word choice, the sounds of language, and the use of metaphors and images (ibid).

\subsection{Children Literature: Picture Story Books}

The way of becoming a child reader is through children literature, particularly through picture books which are very significant in gaining visual literacy (Bland, 2013b). A picture book is a work of art as the overall message is transmitted through not only a text but also images. As emphasized by Catalano (2005), individual examination of the visual images of picture books cannot be possible due to their dependence on a series of linked events which include a variety of visual qualities including the illustrations with different design elements, page layout, trim size, and printing quality such as choice of paper and colour as parts of the whole. Similar to drama, a picture book which includes multimodal forms in terms of semantic, aesthetic and emotional aspects enables readers to depict the intended meaning (Wu, 2014). For instance, Maria (2016) clarified how readers can get pleasure when reading a book via a perception of variety in information derived from pictures and texts. Besides, Nikolajeva \& Scott (2000) underlined a more complex dynamic formed through the communication between words which amplify what are emphasized in pictures and pictures which expand the meaning of the words by also evoking the possible ambiguity that might occur due to contradictory interaction when pictures are incongruent with words. In their book, Nikolajeva \& Scott (2013) addressed involving multiple creators with multiple intentions as the reason for the ill-matched relationship between image and text. To reiterate, if a book includes a well-matched relationship between image and text, pictures might become very powerful tools for readers to have new perceptions beyond what is described by the words or the verbal descriptions of images enable readers to reach deep meaning.

Stories either digital or print-based are comprised of chunks. Those with repetitive and predictable formulas and patterns help learners develop cognitive and language skills (Porras González, 2010). Hence, instead of presenting a language through isolated chunks, teachers can design a variety of activities including vocabulary, speaking, listening, reading, writing, and other type of activities such as games, songs, and drama through stories which provide meaningful, interesting, contextualized and rich linguistic input with repetitive and predictable patterns (Çubukçu, 2012; Enache, 2015; Haznedar, 2010; Lwin, 2016; Porras González, 2010; Yenici, 2003; Yıldırım \& Torun, 2014). In addition, as Sipe (2008) assumed, children's meaning making might be frequently engaged via the front endpapers in terms of predictive purposes to be prepared for the story.

Furthermore, real life situations can be incorporated into the classroom through literature as stories with their cross-curricular topics such as history, mythology, social studies, geography, environmental education, and many others include a variety of themes, topics and content together. For many learners from all age groups, a foreign language sounds really foreign with its strange sounds. A real life story with a familiar plot can compensate the distance between learners' world and the language (Y1lmaz \& Karatepe, 2013). As emphasized by Çer (2016) and Çer \& Şahin (2016), appropriate books for children must meet not only literary criteria but also children's characteristics, needs and interests in terms of the characters that should affect them positively apart from plot and message which should be transmitted in children's emotions and ways of understanding. Moreover, Martinez et al. (2017) asserted that children assign meaning by building bridges between their personal experiences and literary text they read.

Children were introduced a variety of canonical characters via whom they might reflect their modes of behaving and several worlds through which they experience many patterns and templates to construct and reconstruct various cultural imaginations based on their conceptual level, which helps children become aware of their own identity as an individual and a social being (Wu, 2014). To reiterate, one of the possible ways for children to visit imaginarily foreign, far away or exotic countries and to experience different languages and lifestyles is via picture books (Maria, 2016). Maria (2016) remarked 
the importance of being skilful and competent authors in children literature as children, from very early ages, with a natural sense of truth, beauty, and quality tend to appreciate the physical, material, sensory aspects of a book.

In their study, Martens, Martens, Doyle, Loomis, \& Aghalarov (2012) revealed that first grade children responded positively to picture books, developed critical thinking skills, and enhanced their comprehension of the text via creating and constructing their own understanding thanks to multimodal components of picture books. As seen, authors of picture books should pay strict attention to the quality of multimodal elements that need to be incorporated in picture books. However, the study conducted by Konomi (2014) who investigated to what extent teachers use visual materials in EFL classrooms in primary education in Korça, Albania revealed that picture books were reported as one of the least frequently used multisensory media by EFL primary school teachers when compared to pictures, posters and postcards.

Furthermore, Catalona (2005) emphasized that trade picture books which are reviewed in professional and literary journals are at high quality in terms of literary and artistic style. Prominent to emphasize, however, is that teachers who are usually expected to be competent in the creation of context-specific suitable materials to meet the needs of the particular group of learners are not sellers but educators (Yangin Ekşi, 2012). As noted by Bland (2013b), primary ELT teachers show resistance to integrate children literature in their teaching due to their lack of knowledge about the potential benefits of picture books. She also remarked that finding the suitable literature for a particular age group has been the subject of many studies due to the rareness of qualified children books to increase their enthusiasm. Moreover, Driggs Wolfenbarger \& Sipe (2007) remarked that it is probable for the informational picture book genre to be integrated in primary classrooms if the books are compatible with the curricular topics. As emphasized by Kennedy (1987), the best way to acquire a better sense of art that an author needs to develop to create a good story is to have experience in writing a story. It is more than probable that teachers tend to use picture books to increase the quality of their teaching when they become the authors of those books. To put it differently, it becomes very difficult for people, teachers or learners to understand what a story means unless they try to craft one.

Students can be given an opportunity to determine what a good work is in any given situation via self-assessment (Boud, 2013). If students are engaged in the formulation of criteria for self-assessment of their products, they will gain deep understanding of what makes up quality product in a specified area (Spiller, 2012). Furthermore, as emphasized by McMillan \& Hearn (2008), when students do selfassessment of their work by thinking critically via identifying differences between current and desired performance, they take charge of their own learning, which promotes their intrinsic motivation and learning. Self-assessment becomes emancipatory when students contribute to their self-knowledge and understanding (Boud, 2013). Moreover, by examining the differences among the students' selfassessments of their academic experiences qualitatively, Tan (2008) remarked the importance of empowering students in self-assessment practices in higher education contexts through not only gaining self-assessment skills but also enhancing their capacity for life-long learning.

Reviewing the related literature, the researcher found out that trade picture books have been examined in different studies from various perspectives by taking both literature and art into account (Catalano, 2005; Çer \& Şahin, 2016; Gönen, Uygun, Erdoğan \& Katranc1, 2012; Maria, 2016; Wagner, 2013; Wu, 2014). Notwithstanding, there appears a gap in the literature with regard to the evaluation of teacher generated and context specific picture story books aiming to promote children's foreign language development.

Thus, the study aimed to fill the gap in literature by investigating the ELT PTs' self-assessments of their own literary products by forming the following research questions:

1. How do ELT prospective teachers evaluate the quality of their picture story books in terms of some basic literary elements?

2. How do ELT prospective teachers evaluate the quality of their picture story books in terms of responding to the characteristics and needs of the children?

3. To what extent do the experts agree with the ELT prospective teachers on the quality of their picture story books? 


\subsection{Research Design}

\section{METHOD}

A mixed method research design was used to answer the aforementioned research questions by following mainly the quantitative method via the self-assessment questionnaire, and secondly the qualitative method through conducting a semi-structured interview to triangulate the findings of the quantitative data.

\subsection{Setting and Participants}

The study was conducted with 101 (75 female \& 26 male) third year ELT students of Uludag University enrolled in 4 classes of "Teaching English to Young Learners (TEYLs) II" course with two hours of theory and two hours of practice. In TEYLs I course placed in the fifth term of ELT program, the PTs are equipped with knowledge regarding basic principles of TEYLs, children's characteristics, some basic learning theories, teacher talk and support, classroom management, planning a lesson with child- appropriate activities and materials, and creating a digital story and planning a digital-story based lesson. On the other hand, in TEYLs II course placed in the sixth term of ELT program, the PTs are expected to develop more specific methodological knowledge about teaching English vocabulary, grammar and language skills besides creating and using child appropriate resources such as puppets, songs, rhymes, games. After performing various tasks (totally 10 tasks per a term) in the 2-hour practice course, in TEYL II course, the participants were asked to create child-appropriate curriculum oriented (compatible with the 2018 ELT Programme) picture story books to be read-aloud by primary English teachers.

Each class was divided into 5 groups of 4-6 members depending on the class size to create picture books for different grades. The grades were assigned by the instructor based on her program to provide variety in the stories. The PTs of class $3 \mathrm{E}(\mathrm{N}=23)$ created picture books for $2^{\text {nd }}$ graders, $3 \mathrm{C}(\mathrm{N}=23)$ for $3^{\text {rd }}$ graders, $3 \mathrm{~F}(\mathrm{~N}=30)$ for $4^{\text {th }}$ graders, and $3 \mathrm{D}(\mathrm{N}=25)$ for $5^{\text {th }}$ graders. The PTs were free to choose one of the units of their target grades. After being informed about the task, they set about creating their picture books.

Involving expert assessment is very important in conjunction with the self-assessment to validate the students' self-assessment. Thus, the other participants of the study were three ELT experts with PhD who had been teaching in their fields more than fifteen years. One expert, the researcher, specialized in TEYLs and the other two experts ( 1 male and 1 female) specialized in literature.

\subsection{Data Collection Procedure}

Data collection process took four weeks for the data gathered by the PTs. In the first week, the participants were asked to create child appropriate and curriculum oriented picture story books after being lectured about the prominent components of picture story books besides evaluating and discussing weak and strong aspects of the previously created books in the two-hour theory course both with the instructor and the peers. The participants completed their books to be used in micro teaching sessions in the two-hour practice course in a week. One of the picture story books is included in the appendix.

The data obtained from the self-assessment questionnaire of the PTs were gathered in the following week by allocating fifteen minutes of every practice course hour. The interviews were conducted during the third and fourth weeks by considering the participants' and the researcher's program.

After finishing 2017-18 Spring Academic Term, the data gathered from the experts were collected during 3 weeks. Each expert was given a week to evaluate 20 picture story books based on the items in the assessment questionnaire completed also by the PTs.

\subsection{Data Collection Instruments}

Firstly, the questionnaire which included a five-point Likert questionnaire ranging from 1 (very poor) to 5 (very good) was applied in the study. The questionnaire which was formed by the researcher by taking into account the related literature was also checked by two experts in the field (one of them was specialized in TEYLs and the other was in literature) to increase the validity of the instrument. 
Based on the feedback given by the expert in literature, two overlapped items (deductive theme and moral values) were redesigned as one item. Since the research questions aimed to reveal the two aspects of the picture story books, the final version of the questionnaire was divided into two categories; the first category with 11 items was about some basic literary elements and the second category with 12 items was related to some particular criteria for TEYLs. Each expert also checked the content of the items in terms of the category they specialized in. The highest point that could be received from the first part of the questionnaire is 55 and from the second part 60 whereas the least point is 11 from the first part and 12 from the second part. Based on the participants' assessments, the highest points gathered form the first part indicate the quality of the picture story books in terms of integrating some basic literary elements and the highest points obtained from the second part display the quality of the books in terms of integrating some particular criteria for TEYLs. The questionnaire revealed a Cronbach's alpha score of $\alpha=.93$ over 23 items.

Secondly, a semi-structured interview was conducted with 10 PTs to delve into the results obtained from the questionnaire. The interview was firstly recorded and later transcribed for the analysis. The interview questions were as follows:

What are the strengths of your picture book?

What are the weaknesses of your picture book?

Finally, 20 picture books created by the PTs were used as the data to be evaluated by 3 experts in the field (one expert, the researcher, in TEYLs and two experts in literature). For the inter-rater reliability, the researcher received training with regard to literature and gave training to the other experts on TEYLs. 20 picture story books created by the PTs were evaluated by these three experts and the inter-rater reliability was calculated in SPSS and found ".704" for the questionnaire. Moreover, based on the analysis of Kendall's coefficient of concordance, it was found that there is a significant concordance ( $\mathrm{W}=0.48, \mathrm{p} . \square 0.00$ ) among the ranks assigned by 3 different judges on 20 different picture story books created by the participants.

\subsection{Data Analysis}

The data emerged from the self-assessment questionnaire completed by the story creators were analysed through SPSS to calculate the descriptive statistics of means and frequencies. Because of the small sample size in the experts group (3 experts), descriptive statistics of the means were used to compare the ratings' of the ELT PTs and the experts rather than independent sample t-test. As for the qualitative data, the inductive content analysis technique was used to analyse the interview extracts of the PTs.

\section{FINDINGS}

In this section, the findings of the study are presented by following the research questions respectively.

\subsection{How do ELT prospective teachers evaluate the quality of their picture books in terms of some basic literary elements?}

\subsubsection{The Quantitative Findings}

The first research question aimed to investigate the participants' evaluation of their story- picture books by taking some basic literary elements into account. Table 1 presents descending mean scores and percentages for every item. 
Table 1. Descriptive statistics of the results with regard to the participants' self-assessment of their picture books in terms of basic literary elements

\begin{tabular}{|c|c|c|c|c|c|c|c|c|}
\hline$\stackrel{\mathscr{E}}{\Xi}$ & $\mathbf{Z}$ & $\begin{array}{l}\dot{\bar{\theta}} \\
\stackrel{0}{0} \\
\dot{0}\end{array}$ & 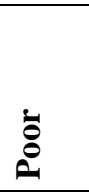 & 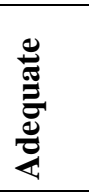 & تُ & 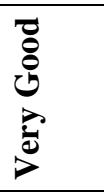 & $x$ & 穴 \\
\hline $\begin{array}{l}\text { 10. Having an effective relationship between the } \\
\text { text and images }\end{array}$ & 101 & 3 & 4 & 7.9 & 26.7 & 58.4 & 4.33 & 99275 \\
\hline 11. Having a deductive theme & 101 & 3 & 4 & 8.9 & 31.7 & 52.5 & 4.26 & .98885 \\
\hline I cover page & 100 & 3 & 5 & 8 & 38 & 46 & 4.19 & .99184 \\
\hline 17. Hav & 101 & 5 & 1 & 16.8 & 26.7 & 50.5 & 4.16 & 1.06836 \\
\hline 7. Having interesting characters & 101 & 5.9 & 6.9 & 10.9 & 26.7 & 49.5 & 4.06 & 1.19380 \\
\hline 19. Having melodic sentences & 100 & 2 & 3 & 22 & 37 & 36 & 4.02 & .94259 \\
\hline ms of mood & 100 & 1 & 6 & 17 & 45 & 3 & 3.99 & .90448 \\
\hline 22. Involving st & 100 & 2 & 5 & 17 & 48 & 28 & 3.95 & .914 \\
\hline 16. Having a well-planned plot & 100 & 2 & 3 & 27 & 35 & 33 & 3.94 & .95155 \\
\hline 15. Having an effective setting in & 99 & 2 & 3 & 24.2 & 41.4 & 29.3 & 3.92 & .91754 \\
\hline 13. Having an effective setting in terms of place & 101 & 4 & 7.9 & 21.8 & 43.6 & 22.8 & 3.73 & 1.02850 \\
\hline
\end{tabular}

Based on the mean scores presented in Table $1(M=4.33)$, having iconotext was ranked as the most successful aspect of the participants' story-picture books. Majority of them (\%85.1) were mostly satisfied with their picture books in terms of providing an effective relationship between the text and images.

Moreover, as a proof of their intention of children's learning something from their picture books, majority of the participants (84.2\%) reported that the themes of their stories were deductive $(M=4.26)$. Regarding the themes, 7 stories were related to friendship, 6 of them were about helping other people and animals, and 1 of them was related to environmental issues.

Furthermore, having a well-designed coverage page $(M=4.19)$ and a comprehensible title $(M=4.16)$ were reported as well-designed parts of the picture story books. Majority of the participants (84\%) reported that the decoration of the coverage page helped the teacher to use pre-story telling techniques. Besides, $77.2 \%$ of them thought that the titles of their stories were comprehensive enough to guess the content of the story.

The other aspects most of the authors were satisfied with their books were about the characters $(M=4.06)$, the sentences $(M=4.02)$ and the settings $(M=3.99)$. Accordingly, $76.2 \%$ of them thought that the characters were interesting for children and $73 \%$ of them stated that the sentences were melodic. With regard to emotional aspect, $76 \%$ of them reported that their stories had effective settings in terms of mood. In line with this, 74 percent of the authors stated that they were successful in involving students emotionally.

The least successful aspects of the picture story books in terms of basic literary elements were reported as having a well-planned plot $(M=3.94)$, an effective setting in terms of time $(M=3.92)$, and an effective setting in terms of place $(M=3.73)$. As for the plot of their stories, only more than half of the participants $(68 \%)$ agreed that their stories had well-planned plots with conflicts to increase students' excitement and involvement. With regard to setting, 70.3 percent of the participants reported that their stories had effective settings in terms of time whereas fewer participants $(66.4 \%)$ were satisfied with their stories' settings in terms of place.

\subsubsection{The Qualitative Findings}

The analysis of the interview extracts indicated mainly five points with regard to literary aspects of the stories such as having an effective relationship between pictures and the texts, theme, emotional involvement of the readers, coverage page, and title. More precisely, most of the interviewees $(\mathrm{N}=8)$ mentioned about the visuality aspect of their story books as the strength of their books. The interview extract below might clarify why they tended to give importance to visual aspects of their stories. 
I8: "The fact that children are at concrete- operational level was frequently emphasized in the lesson directed us to focus on providing more visual guidance. They need visual support. Otherwise, they can't depict meaning only through the text".

Some of the interviewees $(\mathrm{N}=6)$ explained how they considered emotional aspects when preparing their books as seen in the following extracts:

I6: "When choosing the pictures of our characters, we didn't stick the photos directly. We made the faces of animals bigger and chose happy faces to develop positive emotions towards animals".

19: "...For instance, when our character Alice was late for her home, we tried to reflect her fears through pictures as she was afraid of both dark and her mother's becoming angry at her".

Moreover, 5 of the interviewees mentioned about the themes of their stories as a strong aspect including the interviewee 5 as indicated below:

I5: "School age children are familiar with social sharing and having a good relationship. Thus, we chose friendship to provide positive messages". below:

Finally, 2 of interviewees focused on the coverage page and the title of their stories as displayed

I1: "We tried to decorate our coverage page in an interesting way. It was silvery and green so that students' curiosity could be increased. We thought that students would be excited and curious about the story. However, I now noticed that we didn't consider pedagogical aspect of coverage page but only ornamental aspect".

I8: "We consider that when the children see the picture book and its title at first sight, they need to be impressed. We aimed to take children's attention, increase their curiosity, and provide some elements to help children guess about the story."

\subsection{How do ELT prospective teachers evaluate the quality of their picture books in terms of responding to the characteristics and needs of the children?}

\subsubsection{The Quantitative Findings}

The second research question aimed to investigate the participants' evaluation of their storypicture books by taking the characteristics and needs of the children. Table 2 presents descending mean scores and percentages for every item.

Table 2. Descriptive statistics of the results with regard to the participants' self-assessment of their picture books in terms of the particular criteria for teaching young learners

\begin{tabular}{|c|c|c|c|c|c|c|c|c|}
\hline$\stackrel{\mathscr{E}}{\Xi}$ & $\mathbf{Z}$ & 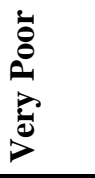 & $\stackrel{\overline{8}}{2}$ & 莺 & $\begin{array}{l}\text { Z } \\
8 \\
\end{array}$ & $\begin{array}{l}20 \\
0 \\
0\end{array}$ & $x$ & ค \\
\hline 6.Having familiar characters & 100 & 2 & 3 & 7 & 27 & 61 & 4.42 & .90095 \\
\hline 5. Curriculum oriented script in terms of grammar & 101 & 2 & 2 & 7.9 & 29.7 & 58.4 & 4.40 & .87382 \\
\hline 9. Having easy- to- read sentences & 101 & 2 & 2 & 17.8 & 41.6 & 36.6 & 4.08 & .89553 \\
\hline $\begin{array}{l}\text { 4. Curriculum oriented script in terms of } \\
\text { vocabulary }\end{array}$ & 101 & 1 & 6.9 & 16.8 & 33.7 & 41.6 & 4.07 & .97656 \\
\hline 8. Having $i+1$ level language & 101 & 2 & 5.9 & 18.8 & 31.7 & 41.6 & 4.04 & 1.01367 \\
\hline 2. Having a fun script & 99 & 4 & 4 & 20.2 & 35.4 & 36.4 & 3.95 & 1.04900 \\
\hline 3. Activating students' imagination & 101 & 4 & 6.9 & 23.8 & 32.7 & 32.7 & 3.83 & 1.08692 \\
\hline 12. Having an amusing theme & 101 & 1 & 12.9 & 27.7 & 30.7 & 27.7 & 3.71 & 1.04246 \\
\hline 21. Involving students' personal experiences & 99 & 12.1 & 15.2 & 15.2 & 21.2 & 36.4 & 3.54 & 1.42337 \\
\hline 23. Appropriacy for drama activities & 100 & 6 & 23 & 15 & 27 & 29 & 3.50 & 1.29099 \\
\hline $\begin{array}{l}\text { 20. Involving students physically through some } \\
\text { items (puppets, attachable/ three dimensional } \\
\text { items) }\end{array}$ & 100 & 4 & 16 & 24 & 38 & 18 & 3.50 & 1.08711 \\
\hline 1. Involving creativity & 100 & 4 & 19 & 24 & 32 & 21 & 3.47 & 1.14111 \\
\hline
\end{tabular}


As indicated in Table 2, the most successful aspects of their stories were about story characters $(M=4.42)$, compatibleness of the script with the curriculum chunks $(M=4.40)$ and the words $(M=4.07)$, readability of the sentences $(M=4.08)$, language level of the texts $(M=4.04)$. Based on the frequency analysis, most of the participants $(88 \%)$ were satisfied mostly with the characters in terms of their familiarity to children and the sentences which were easy-to-read (78.2\%). With regard to writing curriculum oriented scripts in terms of chunks and words, the participants thought that their scripts were compatible with the curriculum in terms of the chunks $(88.1 \%)$ more than the words $(75.3 \%)$. In line with well-integrated chunks, most of the participants (73.3\%) considered themselves as successful in keeping the language of the script at $i+1$ level to challenge the learners.

Furthermore, $71.8 \%$ of the participants thought that the script was fun. On the other hand, with regard to imagination and amusement which are very prominent concepts for children, only more than half of participants stated that their scripts could activate children's imagination (65.4\%) and the themes of their stories were designed to amuse children (58.4\%). Based on the mean scores, the following aspects of the picture story books were ranked as the least successful ones; involving students' personal experiences $(M=3.54)$, appropriacy for drama activities $(M=3.50)$, and involving students physically $(M=3.50)$. To reiterate, only $57.6 \%$ of them claimed that their stories were designed to involve students' personal experiences. Additionally, only $56 \%$ of them pointed out that their stories were appropriate to be used in drama activities as a post-story telling activity and they were designed to involve students physically. Finally, with the lowest mean score $(M=3.47)$, creativity was found as the least successful aspect of the stories. 53\% of them believed that their picture story books were creative.

\subsubsection{The Qualitative Findings}

Three points emerged from the analysis of the interview extracts with regard to the characteristics and needs of the children such as using repetitive words and chunks which are compatible with the current curriculum and creativity. The following extracts might shed light on why it was more difficult for the participants to integrate the target words than the chunks:

I2: "Chunks could be taught through repetitions. Chunks were useful. It is easier to communicate through chunks. On the other hand, when integrating the target words, you need to consider from three aspects: semantic, pronunciation and written aspect. It was difficult to achieve all of them in our picture books".

I9: "Integrating the chunks and words together was really difficult. When using chunks, we have fluency and they flow. But for a word, you have a limitation: An apple is an apple, namely".

Additionally, one of the interviewees explained why it was difficult to be creative when creating their story books:

I3: "When we choose the topic from the curriculum, the topic and the target words are ready for us. For instance, we chose the unit "Animal Shelter". Thus, the characters were animals, the place was animal shelter, and the time was one day. We gave primary importance to what is emphasized in the curriculum and what your expectations are from us. Thus, we didn't feel free to be more creative. There were some limitations that hindered our creativity".

\subsection{To what extent do the experts agree with the ELT prospective teachers on the quality of their picture story books?}

Although the study mainly focused on the PT' self-assessments of their picture story books, it also included the experts' ratings to reveal to what extent they agree on the authors' assessments. Getting agreement from the experts is very important to validate the PTs' self-assessment.

According to the descriptive statistics of the means, there appears a consensus between the PTs and the experts about the following strengths of the picture story books. To illustrate, both the authors $(M=4.33)$ and the experts $(M=4.26)$ agreed on the quality of the story books in terms of having iconotexts, which means that the pictures and the texts were well-matched. In addition, both the experts $(M=4.86)$ and the creators $(M=4.40)$ agreed that the stories were compatible with the curriculum in terms of grammar. Furthermore, as for the characters of the stories, not only the experts $(M=4.25)$ but also the creators $(M=4.42)$ thought that the characters were familiar to children. 
Similarly, both groups were not satisfied with some aspects of the stories. For instance, with the same mean scores $(M=3.83)$, both groups were not so satisfied with the stories in terms of activating students' imagination. Moreover, the mean scores of the experts $(M=3.83)$ and of the creators $(M=3.71)$ were not so high related to having an amusing theme. Furthermore, involving students' personal experiences into the stories was ranked among the least successful aspect of the stories not only by the experts $(M=3.83)$ but also by the creators $(M=3.54)$.

When compared with the PTs' ratings, the experts overrated some of the aspects of the story books. With regard to the target words which were to be included in the stories to meet the requirements of the target curriculum, the experts $(M=4.83)$ overrated the stories when compared to the creators $(M=$ 4.07). Similarly, settings of the stories in terms of place $(M=4.61)$ and in terms of mood $(M=4.50)$ were considered as effective by the experts whereas the creators underrated the settings of the stories in terms of place (3.73) and in terms of mood $(M=3.99)$.

On the other hand, some aspects of the stories were underrated by the expert. For instance, in respect of their books' final physical appearances, namely their coverage pages, it is clear that the creators were satisfied with the coverage pages of their stories $(M=4.19)$ more than the experts $(M=3.50)$. Similarly, the PTs thought that the titles of their stories $(M=4.16)$ were comprehensive enough to guess the content of the stories while the experts underrated the stories in terms of this aspect $(M=3.91)$. Furthermore, although the creators assessed themselves as successful $(M=4.26)$ pertaining to having a deductive theme, the experts did not fully agree with them $(M=3.86)$.

\section{DISCUSSION}

The study aimed to increase the PTs' awareness of children literature by asking them to create child appropriate and curriculum oriented picture story books to be evaluated by themselves in terms of some basic literary elements and appropriacy for young EFL learners. In line with what is emphasized by Bland (2013b) who suggested reconsideration of the role of children literature in teacher education context, the researcher aimed to bring innovation to her TEYLs II course via integrating children literature to the course content.

As suggested by Bhanegaonkar and Mahfoodh (2013), having the required skills to design appropriate materials is very prominent for EFL teachers. Luckily, the overall results of the study revealed that the PTs were successful in creating picture story books meeting both the literary criteria and children's reality. The success of the participants might be attributed to what is underlined by Çer (2016, p.79) who stated that "just like anybody who knows about child reality cannot write children's books, anybody who knows about the attributes of a literature text cannot create children's books without viewing life from their eyes". In other words, the participants not only took TEYL I and II courses through which they became familiar with child reality but also took literature in ELT I and II courses through which they were equipped with the qualifications of a literary text to be used in ELT. Thus, when creating their books, they were likely to consider these two dimensions.

The first research question which sought to find out the PTs' evaluation regarding the quality of their picture story books in terms of some basic literary elements revealed positive results in general. In line with the study of Gönen et al. (2012) which examined 120 picture books and reported that most of the stories were high quality in terms of matching the images with the texts, the books created in this study were considered as high quality both by the authors and the experts in point of creating scripts with well-matched images with the tastes of children and with the educational requirements of the curriculum units. What is more about the stories created in this study is that the participants tried to expand the meaning of the texts not only through pictures but also some tactual materials such as attachable puppets (see appendix 1), puzzles and maps. As evident from the interview results, the success of the authors to be able to create effective iconotexts might be attributed to what is emphasized in the theoretical lessons in which the researcher, as also the lecturer, constantly stresses the importance of providing visual support to enable children at concrete operational level to depict the meaning of the texts.

The findings of the study revealed some questionable points with regard to involving deductive themes, which is also reported in the study conducted by Strouse, Nyhout \& Ganea (2018) who asserted 
that grasping a story's moral and transferring it to the real-world situations are not easy tasks for a child due to a lack of identification with the story characters and analogical reasoning. The findings of the study indicated that the participants involved thematic units successfully and expected young readers to receive intended meanings related to friendship, helping other people and animals in addition to environmental issues.

Based on the mean scores, the PTs indicated lower satisfaction level regarding having effective settings in terms of time and place. When the stories were analysed, it was seen that some of the participants did not mention about setting details in terms of time (see appendix 1) or they mostly used the expression "one day" to refer the time except for two cases in the picture books entitled Saturday's Adventure of Scooby-Doo and Children's Day in which time is given importance and repeated in a few sentences. However, with regard to place, unlike the participants, the experts overrated the stories in terms of place aspect of settings. To put it differently, different places were included in the stories such as forests, magical forests, home, playground, school, park, library, city, and ocean. In addition, they were shown effectively with the help of illustrations. As seen, the places in the stories were chosen from children's immediate environments; thus, they could be accepted as appropriate.

The second research question which was formed to reveal the PTs' evaluation of the quality of their picture story books based on the characteristics and needs of the children indicated positive results as well. In other words, the participants were able to create high quality child appropriate picture story books in which there should be pattern-driven and context-embedded language (Linse, 2006). To be more precise, language could be acquired by comprehensible input which is a little bit beyond students' level of comprehension: $i+1$ (Krashen, 1985). Moreover, Smallwood (2002) indicated some prominent criteria for selecting appropriate children's literature to be used in language learning and teaching such as meeting the curriculum objectives and enhancing the target thematic units, providing repeated and predictable language which should be supported by illustrations and slightly above the level of learners.

Thus, unlike the findings of the study by Gönen et al. (2012) which examined various commercial books and revealed 43 words which were above the students' level, the books created in this study were reported as successful both by the authors and the experts in terms of meeting the educational requirements of the books such as involving the target chunks and the words, easy-to read sentences, which helped the participants to have $i+1$ level language input. Having the aforementioned facilitating items in picture books was also stressed by Linse (2006) who stated that including repetitive language patterns enables students to comprehend the story easily and to construct sentences by dealing with only new vocabulary rather than a variety of grammatical patterns. More than this, aiming to make their books easy to learn and to get benefits from the power of rhymes to both engage and entertain children, the authors successfully composed melodic sentences.

As emphasized by Ghosn (2002), high quality literature should enable readers to understand the feelings of not only self but also others through involving the readers' own life experiences and realities and through developing emotional intelligence. Strouse et al. (2018) suggested that realistic characters and contexts help children derive intended meanings from the stories whereas unrealistic characters and contexts invite children to question whether the information in the stories is realistic or not. Accordingly, the evaluation of the story characters by both the experts and the creators indicated that the characters were familiar to children. Thus, it becomes more likely for children to be able to extract what is emphasized in a theme due to the identification of the story characters. As mentioned by Driggs Wolfenbarger \& Sipe (2007), the more the books are aligned with the content of the required curricular topics the more they are likely to be integrated in teaching. Thus, it is more likely for the participants to integrate their books which were successfully created in terms of their conformity with the target curriculum. However, as one of the interviewees stated, expecting the participants to use the curricular chunks and the words limited their creativity and imagination.

Since transferring a story's lesson into the child's real-world situations is a difficult task due to lack of their analogical reasoning (Strouse et al., 2018), it is very prominent for the story authors to bring children's natural instinct for imagination and creativity into the forefront. Bland (2013b) remarked that imagination, creativity and reflection were considered as postmodern features in children literature to empower learners who were given opportunities to become co-creators. However, nearly 
half of the authors of this study reported themselves unsuccessful in dealing with some features which are very natural part of children's lives such as, imagination, amusement, drama, action, and creativity.

The last research question aimed to reveal to what extent the experts agree with the PTs on the quality of their picture story books. There appeared a consensus between them on the high quality of the books in terms of having iconotexts, curriculum-oriented grammatical patterns, and familiar characters. The agreement between the PTs and the experts indicated that the PTs developed the required skills to create child appropriate story books which also include some basic literary elements to promote children's foreign language development, which was the direct outcome of the study. Additionally, this agreement also remarked the PTs were aware of the purposes and criteria to do the self-assessment besides developing reflecting thinking, which is a valuable indirect outcome of the study. This result is in line with Ratminingsih, Marhaeni \& Vigayanti (2018) who found that university students understood the function of self-assessment.

On the other hand, the disagreement between them indicated the PTs' bias in their assessment. In this sense, there appeared two features in the study, namely coverage pages and titles, which were considered as effective by the authors but underrated by the experts. As understood by the interview results, the participants decorated the coverage pages of the books by considering aesthetic skills more than language skills (see appendix 1), which could be the proof of the PTs' lack of theoretical knowledge on the issue. On the other hand, it is more likely for the experts to take account of language aspects such as activating learners' top-down processes and inviting learners to guess the contents of the stories. The PTs or practicing ELT teachers need to be more aware of the techniques to be used in a pre-story telling phase and make more effort to involve more context clues to be able to decorate more effective coverage pages which might also create a sense of wonder to start to read a picture story book.

Like the PTs, the ratings of the experts were not so high in respect of reflecting the natural needs of children, namely activating their imagination and amusing children through themes. As necessitated by prevailing postmodern era, picture book creators need to make it possible that children should find opportunities to participate in meaning making process via their knowledge and experiences (Bland, 2013b). However, both the authors and the experts thought that the stories were not so successful in involving students' personal experiences.

The reasons for the dissatisfaction of the participants with fulfilling the aforementioned children's needs might also be due to their lack of experience in raising and/ or teaching children in their present lives. It is more likely that they might become more fruitful to find features of imagination which lead learners become more creative as they experience in teaching to children as EFL teachers or caregivers. Furthermore, in the study of Gürsoy \& Bag (2018), the groups (one visual and one audio) trained through creative thinking tasks aiming to develop creative thinking skills -fluency, flexibility, originality and elaboration improved their thinking skills; however, the students in the visual group revealed higher creative thinking skills. Similarly, PTs might be trained through creative thinking tasks to improve their creativity and imagination, which enable them to create high quality literary texts to be used in their future language teaching classes.

Although the participants self-assessed the quality of their picture books to a certain extent in this study, there often exists a mystery which attributes every created picture book an unfathomable value to become a piece of literary art. What is revealed in the study is that a person who sets one's heart on creating a piece of literary art appropriate for children needs to endeavour to become competent not only at integrating some basic literary elements but also at meeting the needs of the children. Despite the expert assessment, the study is limited to the use of self-assessment which is relatively idiosyncratic. Thus, involving peer-assessment would increase the validity of the results by providing multifaceted assessment.

\section{CONCLUSION}

The PTs, by being trained to create a child appropriate picture story book, were found to be successful by both themselves and the experts in creating a valuable instructional tool to teach English to young learners. In educational settings, the more ELT prospective and practicing teachers know and experience how to create child appropriate picture story books which are compatible with the curriculum, the more they tend to integrate in their realms of language teaching, which might provide 
many advantages to children who need to develop both positive attitudes towards learning a foreign language and awareness of that language. Thus, as also suggested by Martinez et al. (2017), the implications of the study might be that more ELT programs should consider teaching the format of picture story books to enable ELT prospective teachers to skilfully scaffold the interaction between students and picture story books.

Believing the importance of cross-curricular approach, the researcher who specialized in teaching English to young learners cooperated with the other teacher educators specialized in literature to become more aware of literature, which might help the researcher as a teacher educator to better design her future teacher education courses when lecturing about children literature. Thus, in the grand scheme of things, teacher educators who specialized in one particular field need to cooperate with other teacher educators who specialized in different fields to enrich their course content and to better educate PTs.

The study is limited to the creation of picture story books; however, the use of literature in ELT is not limited to picture story books. Thus, PTs should be given more opportunities to create variety of literary texts appropriate for teaching English to different age groups to be used in firstly micro teaching sessions in the practice courses of their teacher education program, secondly in their practicum classes, and finally in their future classes. Hence, the experiences of PTs can be examined when creating variety of other literary texts to be used in ELT. Besides, they should also be taught in detail about how to use literary texts in their realms of the classrooms efficiently. Therefore, further research can be conducted to investigate the effects of integrating literature, particularly picture story books, in children's language development.

\section{REFERENCES}

Bhanegaonkar, M., \& Mahfoodh,M. (2013). New approach for evaluating EFLM: An eclectic developed checklist. International Journal of Scientific and Research Publications, 3(10), 1-8.

Bland, J. (2013a). Introduction. In Bland, J., \& Lütge, C. (Eds.). Children's literature in second language education (pp1-11). A\&C Black.

Bland, J. (2013b). Children's Literature and Learner Empowerment: Children and Teenagers in English Language Education. A\&C Black

Boud, D. (2013). Enhancing learning through self-assessment. Routledge.

Catalano, D. (2005). The roles of the visual in picturebooks: beyond the conventions of current discourse (Doctoral dissertation, The Ohio State University).

Çer, E. (2016). Preparing books for children from birth to age six: The approach of appropriateness for the child. Journal of Education and Practice, 7(6), 78-99.

Çer, E., \& Sahin, E. (2016). Validity of a Checklist for the Design, Content, and Instructional Qualities of Children's Books. Journal of Education and Practice, 7(24), 128-137.

Çubukçu, F. (2012). Literature. In E.Gürsoy \& A. Arıkan (Eds.), Teaching English to Young Learners: An Activity based Guide for Prospective Teachers (pp. 343-353). Ankara: Eğiten Yayıncılık.

DiYanni, R. (2000). Poetry: An Introduction. McGraw Hill.

Driggs Wolfenbarger, C., \& Sipe, L. (2007). A unique visual and literary art form: Recent research on picturebooks. GSE Publications, 32.

Enache, E. (2015). Teaching English through stories and songs. Resources for English teachers. RATE Issues Winter, 16. ISSN 1844-6159 http://rate.org.ro/blog2.php/ri/teaching-english-through-stories-and

Feldman, D. H. (2004). Child development. (3rd ed.). New Jersey: Pearson Prentice Hall.

Ghosn, I. K. (2002). Four good reasons to use literature in primary school ELT. ELT journal, 56(2), 172-179.

Gönen, M., Uygun, M., Erdoğan, Ö. \& Katrancı, M. (2012). Resimli Çocuk Kitaplarının Fiziksel, İçerik ve Resimleme Özellikleri Açısından İncelenmesi, Eğitim Dergisi, 42(196), 258-272.

Gursoy, E., \& Bag, H. K. (2018). Is It Possible to Enhance the Creative Thinking Skills of EFL Learners through Training?. Advances in Language and Literary Studies, 9(6), 172-182.

Haznedar, B. (2010). A story-based methodology for young learners. In B. Haznedar \& H. H. Uysal (Eds.), Handbook for Teaching Foreign Languages to Young Learners in Primary Schools (253-276). Ankara: Anı Yayıncilik.

Kennedy, X. J., (1987). Literature: An introduction to fiction, poetry, drama, (4th edition). Scott, Foresman and Company. Glenview, Illinois, London, England.

Kierepka, A. (2006). Children's approaches to authentic picture books in the primary EFL classroom. Picture books and young learners of English, 123-130. 
Konomi, D. K. (2014). Using visual materials in teaching vocabulary in English as a foreign language classrooms with young learners. In Proceedings of the International Conference on New Perspectives in Science Education (pp. 256-260). Padova, Italy: Webster.

Krashen, S. (1985). The Input Hypothesis. Harlow: Longman.

Linse, C. (2006). An analysis of predictable picture books: some beginning insights. Picture Books and Young Learners of English. München: Langenscheidt, 71-9.

Lowe, R. (2009). Childhood through the ages. In T. Maynard \& N. Thomas (Eds.), An introduction to early childhood studies. (pp. 21-33) (2nd ed.). London: Sage Publications.

Lwin, S. M. (2016). It's story time!: Exploring the potential of multimodality in oral storytelling to support children's vocabulary learning. Literacy, 50(2), 72-82.

Maria, B. C. (2016). A special case of intermediality: interanimation of text and pictures in English-speaking picture books. Практики и интерпретаџии: журнал филологических, образовательных и культурных исследований, 1(4).

Martens, P., Martens, R., Doyle, M. H., Loomis, J., \& Aghalarov, S. (2012). Learning from picturebooks: Reading and writing multimodally in first grade. The Reading Teacher, 66(4), 285-294.

Martinez, M. G., Yokota, J., \& Temple, C. (2017). Thinking and Learning Through Children's Literature. Rowman \& Littlefield.

McMillan, J. H., \& Hearn, J. (2008). Student self-assessment: The key to stronger student motivation and higher achievement. Educational Horizons, 87(1), 40-49.

Millett, N. C. \& Rodrigues,R. J. (1991). Explorations in literature America reads. Scott, Foresman and Company. California, Illinois, New Jersey /USA

MoNE (2018). Illköğretim kurumları (ilkokullar ve ortaokullar) Ingilizce dersi (2, 3, 4, 5, 6, 7 ve 8. Sinıflar) ögretim programi. Ankara.

Nikolajeva, M., \& Scott, C. (2000). The dynamics of picturebook communication. Children's Literature in Education, 31(4), 225-239.

Nikolajeva, M., \& Scott, C. (2013). How picturebooks work. Routledge.

Parayno, Salud M. (1997). Children's literature. Rev. ed. Quezon City: Katha Publishing.

Porras González, N. I. (2010). Teaching English through stories: A meaningful and fun way for children to learn the language. Profile Issues in TeachersProfessional Development, 12(1), 95-106.

Rathus, S. A. (2014). Childhood \& adolescence: Voyages in development. (5th ed.). Belmont, CA: Wadsworth.

Ratminingsih, N. M., Marhaeni, A. A. I. N., \& Vigayanti, L. P. D. (2018). Self-Assessment: The Effect on Students' Independence and Writing Competence. International Journal of Instruction, 11(3), 277-290. doi: 10.12973/iji.2018.11320a

Sipe, L. R. (2008). Storytime: Young children's literary understanding in the classroom. Teachers College Press.

Smallwood, B. A. (2002). Thematic Literature and Curriculum for English Language Learners in Early Childhood Education. ERIC Digest.

Spiller, D. (2012). Assessment matters: Self-assessment and peer assessment. New Zealand: Teaching Development, University of Waikato.

Strouse, G. A., Nyhout, A., \& Ganea, P. A. (2018). The role of book features in young children's transfer of information from picture books to real-world contexts. Frontiers in psychology, 9, 50.

Tan, K. H. (2008). Qualitatively different ways of experiencing student self-assessment. Higher Education Research \& Development, 27(1), 15-29.

Wagner, L. (2013). By the numbers: A quantitative content analysis of children's picturebooks. Frontiers in psychology, 4, 850 .

$\mathrm{Wu}, \mathrm{S}$. (2014). A multimodal analysis of image-text relations in picture books. Theory and Practice in Language studies, 4(7), 1415.

Yangın Ekşi, G. (2012). Materials. In Esim Gürsoy \& Arda Arıkan (Eds.). Teaching English to Young Learners: An Activity-based Guide for Prospective Teachers (pp. 33-57). Ankara: Eğiten Kitap.

Yenici, E. (2003). The influence of storytelling on the development and retention of L2 vocabulary in child L2 Learners (Unpublished master's thesis). University of Bosphorus.

Yildirim, R., \& Torun, F. P. (2014). Exploring the Value of Animated Stories with Young English Language Learners. Turkish Online Journal of Educational Technology-TOJET, 13(4), 47-60.

Yılmaz, D. \& Karatepe, Ç. (2013). Contextualization in the EFL primary classroom: A neglected issue in teacher education. In O. Strelova, I. Hristov, K. Morton, P. Peeva, R. Sam. E. Galay, E. Atasay (Eds.). The Science and Education at the Beginning of the 21st Century in Turkey, 3 (57-70). Sofia: St Kliment Ohridsky Univ Press. 
Appendix 1. Pictures of one of the Picture Story Books Created by ELT Prospective Teachers

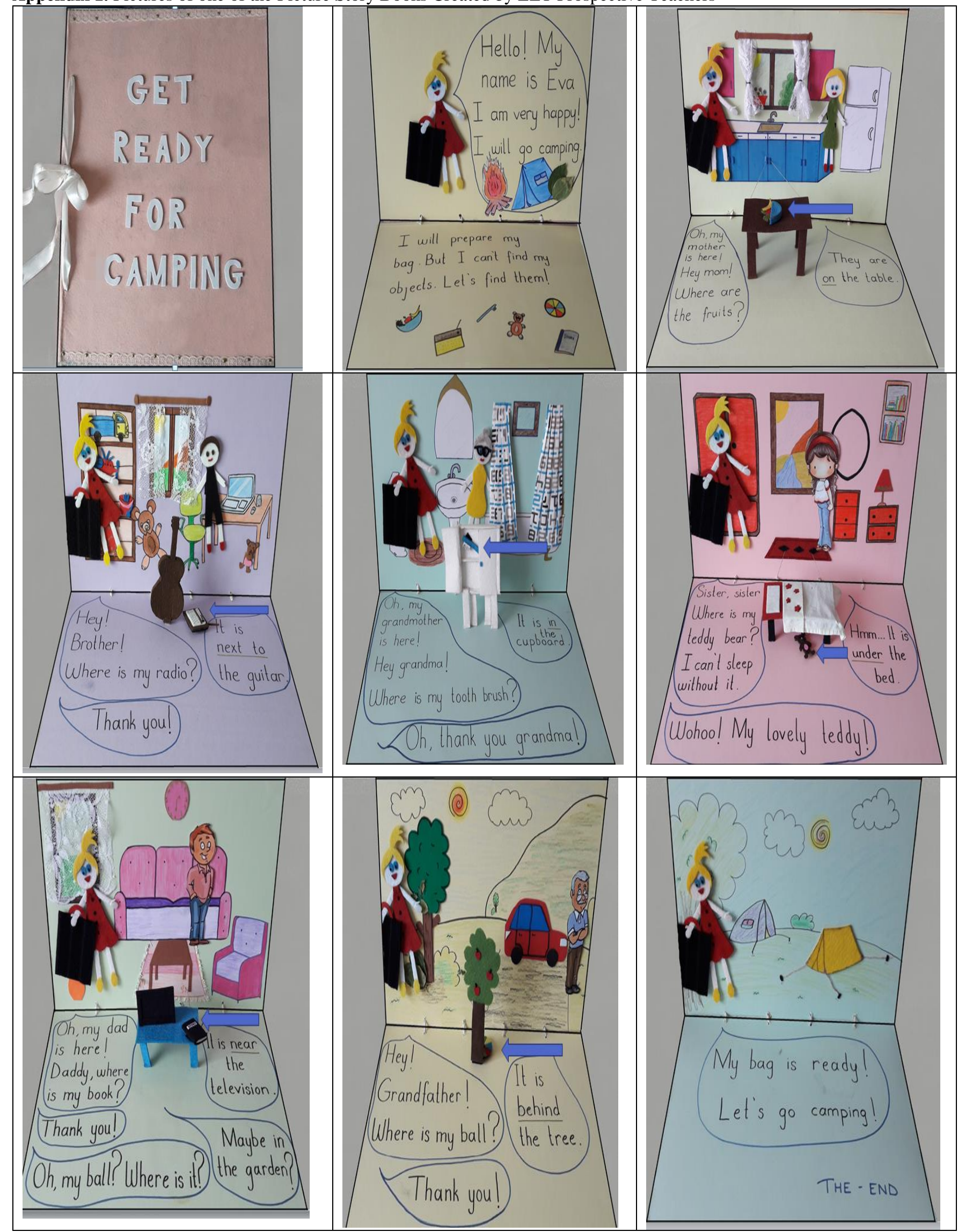

